are given-one representing the absorption of oxygen by the materials as tested, and the other the absorption calculated for "pure gutta," since here also it is mainly this constituent by which the absorption takes place. results of a complete chemical analysis of the identical specimens of gutta percha used for the determination of the specific gravity and the experiments on the absorption of water and oxygen.

Experiments were also shown to demonstrate the remarkable difference in the behaviour of gutta percha and caoutchouc towards ozone, thin tissue of the former resisting the action of caoutchouc membrane was pierced by a jet of this gas impinging on it in a few moments. The lecturer also spoke of the applica tions of gutta percha hardened by extraction of the resin according to his process, proposing it for the use of boats for the arctic regions, on account of its considerably greater strength than that of ordinary gutta percha at very low temperatures, which was demonstrated by experiments.

$\mathrm{He}$ also showed that the elasticity of golf balls, as shown by the height of rebound when allowed to drop on a stone slab, depended almost entirely on the percentage of resin in the gutta
The appendix to the lectures, given in the reprint, contains the strongly ozonised oxygen for a considerable time, whereas a

doubtless be of interest. The skull, that of a Hartebeest, was exhibited at the Linnean Society on January 20 last, and is the original of the sketch; the cocoons are cylindrical and closed at the outer end like the fingers of a glove, extremely tough and composed of a dark grey felt substance, evidently the comminuted fibres of horn, the largest being about three inches in length; these cocoons are formed by the horn-feeding larvæ of the moth known as the Tinea vastella, and the following is a description of the insect :-Very pale gilded ochraceous shining. Head ochraceous and tufted above, palpi porrect, pubescent, extending a little beyond the front, much shorter than the breadth of the head, third joint lanceolate, much shorter than the second. Abdomen extending much beyond the hind wings. Legs rather long, hind tibiæ thinly fringed. Wings long, narrow, fringe rather long, fore wings slightly acute, exterior border very oblique, under side and hind wings purplish cinereous, excepting the fringe. Length of the body seven lines, of the wings sixteen lines.

A very interesting point with regard to the habits of this insect, which has not yet been cleared up, but upon which I hope to be able to throw some light, through the observations of

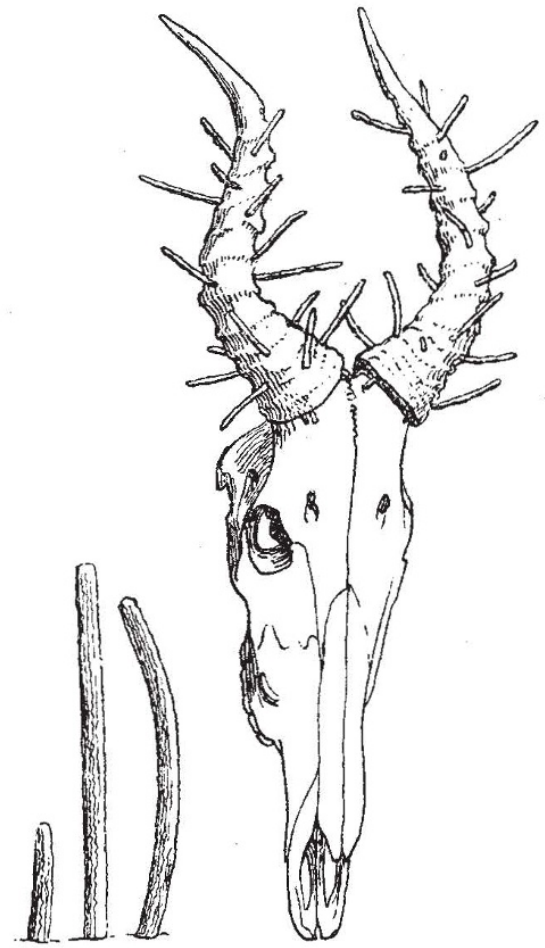

Cocoons natural size. Skull and horns $\frac{1}{8}$ natural size.

percha of which they are made; and consequently the treatment by the hardening process is now invariably resorted to, except in the case of gutta percha obtained from leaves by chemical precipitation processes, which consists almost entirely of pure gutta, as has been already mentioned.

\section{HORN.FEEDING LARVAE.}

SOME few months ago I received a consignment of skulls of antelopes from West Africa, the specimens having been shot by the late Lieut. R. H. McCorquodale, 3 rd Dragoon Guards, and on opening the cases I was much struck by the appearance of the horns; all, without exception, were infested by singular thin finger-like protuberances which seemed to grow from the horn, leading me at a first impression to the immediate conclusion that they were some species of fungi; on a nearer inspection I found them to be cocoons, and not having seen anything like them before I looked into what literature I could find on the subject.

As it is, generally speaking, only travellers, or those in touch with travellers, who have the opportunity of seeing the actual cocouns on the horns, a sketch and a few salient points will

$$
\text { NO } 1493 \text {, VOL. } 58 \text { ] }
$$

officers now serving in Africa, is, that it has been asserted to feed on the horns of living animals; and in support of this I will quote the following:--Dr. Fitzgibbon many years ago while in Gambia stated he was surprised at finding grubs enclosed in cases, which projected from the horns of animals freshly killed, the blood not being yet dry, the carcases of the animals being exhibited in the market place." This statement is recorded in vol, i. of the Proceedings of the Dublin Zool. Soc. "In contradiction, Lieut. -Colonel Wenman Coke said he had shot large numbers of various species of horned animals in South Africa. but that he had never seen the horn of a living animal perforated by one of these larvæe, although he had seen many dead horns infested with them. Colonel Coke is most confident that the larvæ never attacks a living animal; he says that had this been the case it could not have escaped his observ. ation; Mr. Truman concurs in expressing great doubt as to the correctness of the theory that the larva feed on the horns of living animals." We have the strong evidence of Dr. Fitz. gibbon, and might argue that, as the fibrous substance of the horn undergoes little or no change at the death of the animal, there seems no reason why the moth should not deposit its eggs 
when the living animal is at rest, nor why the larvæ should not penetrate the horn. I venture to assert as my own opinion, and that of many sportsmen from whom I have made inquiries, that the larvæ does not feed on the horns of living animals; had this been the case, it would not have escaped the observation of some of our " mighty African hunters." Thus Dr. Fitzgibbon's statement stands alone; the question must, however, remain sub judrce.

The habitat of the moth was generally supposed to be Africa, but Sir George Hampson showed me some specimens which he had collected in various districts in India.

I am indebted to Lord Walsingham, who kindly gave me some very useful notes, he having himself written a few years ago on the subject; also to Mr. P. H. Miller for a very faithful sketch. W. H. MCCorquodale.

\section{UNIVERSITY AND EDUCATIONAL} INTELLIGENCE.

CAMBRIDGE.-In connection with the Congress of Physiology and the Congress of Zoology to be held in Cambridge towards the end of August, the University proposes to confer the honorary degree of Doctor of Science on the following distinguished foreign representatives. For Physiology : Prof. Bow ditch, Harvard ; Prof. Golgi, Pavia ; Prof. Kronecker, Berne Prof. Kühne, Heildeberg; and Prof. Marey, Paris. For Zoology : Dr. Anton Dohrn, Naples; Prof. Milne-Edwards, Paris ; Prof. Haeckel, Jena ; Prof. Hubrecht, Utrecht; and Prof. Kowalevsky, St. Petersburg.

The annual report of the Museums Syndicate testifies to the great activity of the science departments and the ever-growing importance and value of the collections acquired by the University. Numerous expeditions have left Cambridge to prosecute researches in far distant lands, and have returned with important and extensive trophies of their work. South America, through Mr. Graham Kerr and Mr. Budgett, has yielded some fine zoological series. The South Pacific fauna has been illustrated by the spoils of Mr. Stanley Gardiner of the Funafuti expedi tion. Dr. Willey has brought unique contributions from New Britain; and both he and Prof. Flinders Petrie have greatly enriched the magnificent collection of crania under the charge of Prof. Macalister. Other additions are due to Dr. Haddon (Torres Straits), Sir W. L. Buller (Macquarrie Island), Prof. Wiltshire and Mr. H. H. W. Pearson (Ceylon), and many other workers and benefactors.

Mr. Frank Morley, of King's College, the author of numerous works and memoirs in pure mathematics, has been approved for the degree of Sc.D.

The complete list of matriculations for the year has now been published. It appears that 93I students have joined the University in 1898 , as compared with 887 in the preceding year.

Dr. Alex. Hill has been re-elected Vice-Chancellor for the ensuing academical year.

Mr. R. Pendlebury, and Mr. A. E. H. Love, F.R.S., Fellows and Lecturers of St. John's College, have been appointed University Lecturers in Mathematics.

A University Lectureship in Chemical Physiology is to be established in connection with Prof. Foster's department, but the University is unable to assign any stipend to the post at present. The lecturer will be remunerated from the students' fees.

Hitherto the same persons have acted as examiners in Anatomy and in Physiology respectively for the Natural Sciences Tripos, Parts i. and ii., and for the Medical examinations. The number of candidates has increased so largely (it is now 3 ro in physiology, and 252 in anatomy! that the work involved is too much for one pair of examiners. It is accordingly proposed to divide the duty by appointing separate examiners for the Tripos and for the M.B. examinations.

Prof. E. B. Frost, of Dartmouth College, has been elected professor of astrophysics at Yerkes Observatory; and Prof. E. F. Nichols has been appointed professor of physics in Dartmouth College.

Mr. William Butler Duncan, of New York City, has presented to Yale University the Hotel Majestic at New Haven, to be used as a dormitory, and to be called the Duncan Dormitory.

NO. I 493 , vOL. 58$]$
In replying to questions referring to the Government measures which it is intended to bring forward shortly, Mr. Balfour informed the House of Commons on Monday that the Lord President of the Council would introduce, " in another place," a Bil dealing with the organisation of secondary education, and he hoped the London University Bill would be passed.

ABout a year ago the Lords of the Committee of Council on Education decided to make inquiries as to the number of pupils in public and private secondary and other schools (not being public elementary or technical schools) in England, and the teaching staff in such schools. These schools are very various in character, in constitution, and in size; but, broadly speaking, they furnish to the country what is known as secondary or intermediate education in its different grades, and fill the gap between the public elementary schools and the universities or university colleges. They include schools in which educational efficiency is at a minimum, and schools (unfortunately but a small proportion) where rational methods of instruction are followed. The results of the inquiries made through the Education Department have just been published in a Blue Book. The Return represents the first attempt which has been made in this country to give a statistical survey of the schools in the great province of national education which is intermediate between the public elementary schools and institutions of academic rank or for technical training. It shows the various forms of control and ownership under which these schools are carried on, but, as they do not come under any comprehensive system of inspection, no pronouncement can be made as to their educational efficiency or inefficiency. The number of pupils in the 6209 schools comprised in the Return are 291, 544; of these 158,502 are boys, and 133,042 are girls. Only 9 per cent. of the boys are more than sixteen years of age, and I I per cent. of the girls. As to the staff, $3^{2}$ per cent. of the boys' schools are without graduates on the attached staff, $73^{\circ} 8$ per cent. of the girls' schools, and $8 \mathrm{I}^{\prime} 3$ per cent. of the mixed schools. From this it will be seen that $61 \cdot 6$ per cent. of all the schools on the Return have only non-graduates on the exclusively attached staff. Of course, this division into schools with graduates and without graduates on the staff only affords a rough criterion as to the character of the instruction, for graduates are not necessarily good teachers, nor are good teachers necessarily graduates. It is, however, time that steps were taken to insist upon all private schools giving public guarantees of their educational efficiency.

\section{SOCIETIES AND ACADEMIES, LONDON.}

Linnean Society, May 5.-Dr. A. Günther, F.R.S., President, in the chair.-Dr. Bernard Renault and Prof. Max Carl Wilhelm von Weber were elected Foreign Members of the Society.-A paper was read by Sir John Lubbock, Bart, M.P., F.R.S., on some Spitsbergen Collembola. Owing to the wellknown tolerance of cold by insects belonging to this order, it was, he thought, not surprising that several species should occur in Spitsbergen. Eleven species of Collembola had been found in Greenland, as recorded by Meinert (Vidensk. Meddel., 1896, pp. I $67-173)$, and five species were already known from Spitsbergen. He was now able to add two more, one of which was new. This he proposed to call Isotoma spitsbergenensis. The second species, Isotoma quadrioculata, had been previously met with in Greenland. Both of these were obtained by $\mathrm{Mr}$. Trevor Battye during Sir Martin Conway's expedition to Spitsbergen in I896. - Miss Ethel Barton, by permission of the President and Council, read a paper on the structure and development of Soranthera, a genus of brown Algre (Pheophycece) containing a single species, $S$. alvoidea.-Mr. J. T. Cunningham read a paper dealing with the evolution of animal structure, and entitled "The Species, the Sex, and the Individual." The general conclusion arrived at by the author was that adaptation was not produced indirectly by selection from indefinite varia. tions, but directly by the influence of stimulation in modifying the growth of the parts or organs of the body.

Geological Society, May I8.-W. Whitaker, F.R.S., President, in the chair.-The garnet-actinolite schists on the southern side of the St. Gothard Pass, by Prof. T. G. Bonney, F.R.S. The author described the field relations and the microscopic structures of a group of schists or gneisses characterised by the frequent presence of conspicuous garnets and actinolites, 